\title{
Accounting Experiences In Collaborative Learning
}

Tracie Edmond, Ph.D., CPA, University of the Incarnate Word, USA

Theresa Tiggeman, CPA, University of the Incarnate Word, USA

\begin{abstract}
This paper discusses incorporating collaborative learning into accounting classes as a response to the Accounting Education Change Commission's call to install a more active student learner in the classroom. Collaborative learning requires the students to interact with each other and with the material within the classroom setting. It is a departure from the traditional lecture method of teaching. Additionally, the paper addresses opposition and support of collaborative learning. Obstacles to collaborative learning are delineated and strategies to counteract these obstacles are explained.
\end{abstract}

Keywords: Collaborative Learning, Accounting

\section{INTRODUCTION}

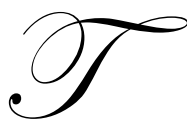

here is beginning to be a paradigm shift in the way accounting classes are taught. The shift is from the traditional lecture format to a more active and team learning format. There are two main reasons for this shift. The first reason is due to the Accounting Education Change Commission's pronouncements encouraging universities to involve the students more in the learning process. In essence these pronouncements emphasize that:

1. The student should be an active participant in the learning process

2. The student should be taught to identify and solve unstructured problems that require use of multiple information sources

3. The student should learn by doing

4. The student should learn to work in groups

5. The students should be taught the creative use of technology (Saunders \& Christopher, 2003)

The second reason for this shift is that many accounting departments are trying to incorporate and instill the American Institutes of Certified Public Accountant (AICPA) personal competencies in their accounting students. The AICPA's personal competencies relate to the attitudes and behaviors of individuals preparing to enter the accounting profession. The personal competencies enhance the way professional relationships are handled and facilitate individual learning and personal improvement. The AICPA has seven elements in its personal competencies that should be obtained by anyone entering the accounting professor as a CPA. The seven elements and their descriptions are shown in Table 1.

As a response to the Accounting Education Change Commission pronouncements and the AICPA personal competencies, accounting departments have instituted what some may call non-traditional teaching methods to ensure the students are well-equipped to enter the accounting profession. Based on a survey issued to 325 accounting department chairs across the United States, 15.1\% require an accounting lab, 54.3\% require the use of computers in completing assignments, $20 \%$ require simulations and $60 \%$ require a team-learning approach or collaborative learning (Saunders \& Christopher, 2003). 
Table 1

\begin{tabular}{|c|c|}
\hline AICPA Personal Competencies & Definition \\
\hline Professional Demeanor & $\begin{array}{l}\text { Individuals entering the accounting profession should behave in a manner that is } \\
\text { consistent with the character and standards of the discipline of accounting, } \\
\text { demonstrating objectivity, integrity, and ethical behavior. }\end{array}$ \\
\hline Problem Solving and Decision Making & $\begin{array}{l}\text { Accounting professionals are often asked to discern the true nature of a situation } \\
\text { and then determine the principles and techniques needed to solve problems or } \\
\text { make judgments. Thus, individuals entering the accounting profession should } \\
\text { display effective problem solving and decision-making skills, good insight and } \\
\text { judgment, as well as innovative and creative thinking. }\end{array}$ \\
\hline Interaction & $\begin{array}{l}\text { Work with others to accomplish objectives. Demonstrate ability to work } \\
\text { productively with individuals in a diversity of roles and with varying interests in } \\
\text { the outcome. }\end{array}$ \\
\hline Leadership & $\begin{array}{l}\text { Effectively lead in appropriate circumstances. This involves acquiring the skills } \\
\text { needed to influence, inspire, and motivate individuals and groups to achieve } \\
\text { results. }\end{array}$ \\
\hline Communication & $\begin{array}{l}\text { Communicate financial and non-financial information so that is understood by } \\
\text { individuals with diverse capabilities and interests. Give and exchange information } \\
\text { within a meaningful context and with appropriate delivery. Have the ability to } \\
\text { listen, deliver powerful presentations and produce examples of effective business } \\
\text { writing. }\end{array}$ \\
\hline Project Management & $\begin{array}{l}\text { Manage a diversity of projects throughout a career. Demonstrate the ability to } \\
\text { effectively control the course of a multi-dimensional, multi-step undertaking. This } \\
\text { includes managing project assets, including human, financial, property, and } \\
\text { technical resources. }\end{array}$ \\
\hline Leverage Technology & $\begin{array}{l}\text { Technological adaptability is a requirement for today's accounting professional. As } \\
\text { technology advances, accounting professionals must acquire new skills and } \\
\text { determine how new technologies should be best incorporated into their practices. } \\
\text { This commitment to continual technological learning will enhance the } \\
\text { development and application of other personal competencies (American Institute } \\
\text { Certified Public Accountants, n.d.). }\end{array}$ \\
\hline
\end{tabular}

\section{OPPOSITION TO THE USE OF THE TEAM LEARNING APPROACH}

While the survey above displays the fact that many universities are beginning to utilize a team approach or a collaborative learning approach in their accounting classes, there is some opposition or criticisms to using the a collaborative learning approach. According to Holt, Michael and Godfrey collaborative learning leads to inefficient allocation of student time and that the inefficiency in time allocation may reduce student knowledge. Another criticism is the allocation of grades, because in team assignments, the same grade is usually given to the group, Holt, Michael and Godfrey feel that the group grades limits the ability of students to signal their quality and potential to prospective employers (Holt, Michael, \& Godfrey, 1997). Another opposition stated by Ravenscroft, is the issue of faculty time. Because collaborative learning is a relatively new concept in accounting, faculty need to invest time and effort in learning a new teaching strategy. The final criticism mentioned by Ravenscroft is student reaction. Many students feel negatively about sharing grades, resent students who tag along for the ride or feel uncomfortable with the diffusion of responsibility (Ravenscroft, 1997)

\section{SUPPORT TO THE USE OF THE TEAM LEARNING APPROACH}

In an article that refutes these criticisms, Ravenscroft states that many businesses rely on teamwork to get any job done. In terms of the loss of information value in group grading, Ravenscroft states that: 
"If criterion-referenced grading is used, and more students actually meet higher standards, faculty are generally deemed more successful. Any decline in the variance of grades must be measured against the value of betterprepared graduates" (Ravenscroft, 1997, p. 189).

Ravenscroft goes on to elaborate that studies have shown that employers and graduate admissions officers need to rely less heavily on grades (which are not a very good predictor of career success), and refine their hiring criteria. By making this change, employers could potentially, reduce their hiring and training costs. In terms of faculty time, Ravenscroft discusses that an increase in time is not specific to cooperative learning, however, but applies to any new pedagogy. In terms of negative student reaction, Ravenscroft emphasizes that when students become employed, the student will face the issues of sharing responsibility, and working in teams with members that are not pulling their weight. She also discusses that as students learn to help others gain an understanding of the material, the students themselves are gaining a better understanding.

\section{PITFALLS TO SUCCESSFULLY USING COLLABORATIVE LEARNING TECHNIQUES IN ACCOUNTING CLASSES}

If, after careful analysis, an accounting professor is persuaded to utilize collaborative learning techniques, then the professor needs to be aware of seven pitfalls to successfully implementing these techniques in the classroom. First, the students may not instinctively work well collaboratively, with some students even letting the more driven students do all of the work. Second, many professors may be tempted to let the students form their own groups, in fact, best friends do not necessarily make the most productive groups. Third, a professor may want to make the group sizes large; fourth, professors may get discouraged and decide to dissolve the groups too quickly. Fifth, professors may encounter a quiet or shy student and the student may feel left out or not want to participate in the group. Sixth, on the opposite side of the coin, a professor may encounter an overly dominant student that does not allow the other students to learn. Seventh and last, a professor may be tempted to give the same grade to every group member regardless of the student participation and effort. (Fiechtner \& Davis, 1992); The University of Texas, (n.d.).

\section{STRATEGIES TO OVERCOMING THE PITFALLS}

There are a number of strategies that a professor can use to overcome the above-mentioned pitfalls. In order to overcome the pitfall of students not working collaboratively, the professor needs to structure tasks in ways that require certain kinds of interactions. This could include giving students specific group management role and responsibilities, such as manager, encourager, cheerleader, coach, question commander, checker, or taskmaster. Another strategy to overcome this pitfall is to give each member of the team a different, interdependent research and problem-solving roles can ensure that students work together rather than in parallel. In terms of the group dynamics, the instructor needs to have input into how the groups are forms. As an added tip, heterogeneous groups can minimize the impact of status differences and encourage active participation by female and minority students. Lowability students often benefit most when paired with medium-ability students rather than those of highest ability. Also, smaller groups of no more than four to six work better than extremely large groups, at times a pair of students is an ideal group. Last in terms of group dynamics, allow time for the groups to become cohesive, rather than continually dissolve groups and form new groups. In terms of student personalities, for a quiet or shy student type, the instructor should have students go home and write down their own individual ideas on paper, then each member would be required to share his or her ideas with the group. For a student with a dominant personality, professors should train students in interpersonal communication skills ahead of time so that they know what behavior is expected of the group and require discussion of group functioning, focusing on how students should talk and listen to each other. The final pitfall to overcome is avoiding the temptation to give the same group grade. It is essential that instructors consider assessment strategies carefully, looking for ways to reward the group while also emphasizing individual accountability. Unlike assigning a single shared grade to a group project, multiple group and individual assessments encourage students to work together and minimize "shirking." (Johnson, Johnson \& Smith, 2006). 


\section{CONCLUSION}

In order to meet the requirements of the Accounting Education Change Commission pronouncements and to instill the AICPA personal competencies in accounting students, accounting instructors need to be aware of the paradigm shift from a traditional lecture format to the collaborative learning formats. There are many pitfalls that an instructor may come across during the beginning stages of implementing a collaborative format. This paper addresses some of the more common pitfalls encountered and provides some suggestions for overcoming the challenges associated with collaborative instruction.

\section{AUTHOR INFORMATION}

Dr. Tracie Edmond is an assistant professor of accounting at the University of the Incarnate Word. She is a Certified Public Accountant with over 20 years of industry experience working for Big four accounting firms and fortune 500 companies. Tracie is very active in her community where she serves as an officer on several nonprofit boards; she also serves as the Volunteers in Income Tax Program co-coordinator for the university. Tracie's research interests are in the area of collaborative learning in accounting classes and in nonprofit accounting issues.

Theresa Tiggeman is a professor of accounting at the University of the Incarnate Word.

Additionally, she serves as the Volunteers in Income Tax Program co-coordinator and has worked in this program for 20 years. Currently, her publications focus on interactive continuing professional education courses for Certified Public Accountants. She is a member of many professional organizations and is an active member of the university community. She regularly speaks and writes on tax issues.

\section{REFERENCES}

1. Personal competencies. (n.d.). Retrieved March 15, 2008, from American Institute of Certified Public Accountants Web site: http://www.aicpa.org/edu/pers.htm

2. Collaborative projects: The benefits of collaborative learning. (n.d.). Retrieved March 15, 2008, from The University of Texas Web site: http://www.edb.utexas.edu/visualvoices/organize01.php

3. Fiechtner, S. B., \& Davis, E. A. (1992). Why some groups fail: A survey of students' experiences with learning groups. In A. S. Goodsell, M. R. Maher, \& V. Tinto, Collaborative learning: A sourcebook for higher education. Syracuse University: National Center on Postsecondary Teaching, Learning, \& Assessment.

4. Holt, D. L., Michael, S. C., \& Godfrey, J. T. (1997, Spring). The case against cooperative learning. Issues in Accounting Education, 12(1), 191-193.

5. Johnson, D. W., Johnson, R. T., \& Smith, K. A. (2006). Active learning: Cooperation in the college classroom (3rd ed.). Edina, MN: Interaction Book Company. (Original work published 1991)

6. Ravenscroft, S. P. (1997, Spring). In support of cooperative learning. Issues in Accounting Education, 12(1), 187-190.

7. Saunders, G., \& Christopher, E. R. (2003, September). Teaching outside the box: A look at the use of some nontraditional models in accounting principles courses. The Journal of American Academy of Business, $3(1 / 2), 162-165$. 